\title{
Nye processioner som udtryk for gamle religionsmønstre
}

\author{
KIRSTINE HELBOE JOHANSEN OG MARIE VEJRUP NIELSEN
}

ENGLISH ABSTRACT: This article analyzes two examples of new processions in the Evangelical-Lutheran Church in Denmark, observed in the context of Halloween Services and Baby Hymn Singing activities. These two cases are analyzed from theoretical perspectives that connect approaches from sociology of religion within the study of contemporary religion (McGuire 2002; Ammerman 2016) with history of religion perspectives on the understanding and development of religious rituals (Bellah 1964; Rappaport 1999). Based on this analysis, the article discusses how to understand these re-emerging processions in a contemporary context and argues for a greater focus on the religious didactic dimensions of processions.

DANSK RESUME: Denne artikel analyserer to eksempler på nye processioner $i$ den danske folkekirke observeret i forbindelse med Halloween-gudstjeneste og babysalmesang. Disse to cases analyseres ud fra teoretiske perspektiver der forbinder religionssociologiske tilgange til samtidsreligion (McGuire 2002; Ammerman 2016) med religionshistoriske perspektiver på udviklingen af religiøse ritualer (Bellah 1964; Rappaport 1999). På baggrund af denne analyse diskuterer artiklen, hvordan man kan forstå disse genopdukkede processioner $i$ en nutidig sammenhæng, og der argumenteres for et større fokus på de religionsdidaktiske dimensioner i processioner.

KEYWORDS: processioner; folkekirken; Halloween; babysalmesang; ritualer; religionsdidaktik.

Mens de fleste undersøgelser inden for samtidsreligion fokuserer på det innovative og forandrede i nye religiøse praksisformer og dermed understreger deres forskellighed i forhold til etablerede religiøse praksisformer, søger vi i denne artikel i stedet at pege på, hvordan innovation og forandring opstår ved at genopdage og genindføre basale religionsformer, som ellers har været undertrykt, uglesete eller lige frem forbudt inden for religiøse organisationer. Ud fra et sådant perspektiv skal religiøs innovation ikke først og fremmest forstås som opfindelse af nye religiøse udtryksformer, men som genopdagelse og nyfortolkning af basale religionsformer. I 
centrum kommer ligheder mellem samtidsreligion og historiske religioner frem for forskelle gennem et fornyet fokus på kropslighed og ritualisering som centrale dimensioner i religiøse udtryk også inden for etablerede historiske kirker.

I 1964 så Robert Bellah på sin nærmeste fremtid og beskrev den som et åbent og kreativt felt præget af en høj grad af religiøs innovation, og inden for religionsforskningen er der fortsat bred enighed om, at det religiøse felt er under stor forandring (Bellah 1964). Denne forandring kendetegnes ved globalisering og migration, som medfører en øget religiøs og kulturel pluralitet, hvor en mangfoldighed af religioner og livssyn er umiddelbart tilgængelige for den enkelte (Beckford 2003). Ved social sekularisering, som har medført en øget adskillelse af religiøse institutioner fra offentlige institutioner og myndigheder; og ved individualisering, som har betydet en stigende tendens til og mulighed for at konstruere og åbent vedstå en egen bricolage-religion, som ikke nødvendigvis udfolder sig inden for eller relaterer sig til etablerede religiøse institutioner og betydningssystemer (Bellah 1964; Davie 2000; Heelas 2005). Denne udvikling har medført en stigende opmærksomhed over for religion og religiøsitet, således som den udfolder sig uden for de etablerede religioner og religiøse institutioner, her repræsenteret ved Meredith McGuires brug af begrebet om lived religion, som er udviklet blandt andet af David Hall, og Nancy Ammermans begreb everyday religion (Hall, ed., 1997; McGuire 2008; Ammerman 2007). Samtidigt er der i forskningen i 2000'erne en stigende diskussion af, at lived religion også udfolder sig inden for de etablerede religiøse institutioner (Orsi 2002; Ammerman 2016; Nielsen \& Johansen 2015). Der er således ikke konstruktivt for forskningen at opretholde en entydig grænse mellem privat, levet religion kendetegnet ved innovation på den ene side og officiel religion defineret som konstant og udviklingsresistent på den anden. Også de etablerede religiøse institutioner danner ramme om levet religion, og disses praksisformer er i løbende udvikling og forandring. Denne udvikling danner ramme om artiklens analyse og diskussion af, hvordan vi kan forstå genopdukkede religiøse praksisformer, i dette tilfælde processioner, i dag.

\section{Individuel og kropslig religiøsitet inden for etablerede, historiske kirker}

I denne artikel vil vi fokusere på to eksempler på processioner, som begge er udtryk for en større bølge af nye aktiviteter i den danske folkekirke (Nielsen 2009). En stærk tendens inden for denne bølge er rituel fornyelse. Denne har kendetegnet kirkelivet siden 1990'erne og kan ses som en tilbagevenden til og genopdagelse af rituelle handlinger som forkyndelsesmedium i en tid, hvor sekularisering vinder frem og den traditionelle religiøse oplæring er begrænset (Baunvig \& Johansen 2014). Den rituelle fornyelse skaber mulighed for en mere umiddelbar, ikke-skolet erfaring af kirke og kristendom og har sit ophav i en ændret indstilling til, hvordan man knytter forbindelse til kirkens medlemmer.

Når etablerede religiøse institutioner som den danske folkekirke som respons på forandringer i det religiøse landskab udvikler og genfortolker rituelle handlinger og 
religiøse praksisformer, søger de at skabe nye og mere åbne rum for religiøs selvudfoldelse inden for den etablerede religion. Det er denne bevægelse og den stigende erkendelse af, at også folk, som opretholder medlemskab af en etableret kirke, udlever en sammensat og individuel hverdagsreligion, som har ført til et begyndende opgør med skellet mellem individuel og officiel religion inden for forskningen i samtidsreligion.

Interessen for levet religion eller hverdagsreligion begyndte som et berettiget opgør med religionsforskningens tendens til at undersøge religion inden for de etablerede religioner og oftest med udgangspunkt i den religiøse elite. De nævnte religionssociologer som Meredith McGuire og Nancy Ammerman ønskede at udvide forståelsen af religion til også at inkludere religiøse praksisformer og forståelser, som udfoldede sig uden for den religiøse elite og uden for de velkendte religiøse rum som kirker, moskeer og synagoger. I stedet skulle individers sammensatte religion i fokus, sådan som den udleves i alle mulige forskellige kontekster og sammenhænge.

Det udfolder sig særligt stærkt hos McGuire, som opstiller en skelnen mellem officiel og uofficiel religion. Hvor officiel religion kendetegnes ved stabilitet og konsistens, kendetegnes uofficiel religion ved at være rodet, mangfoldig og under konstant forandring (McGuire 2002). Problemet med dette skarpe skel er, at det bliver svært at undersøge den foranderlige og ikke-konsistente religion, som udfolder sig inden for den officielle religion. Det er denne udfordring, Ammerman gør status over i sin artikel (Ammerman 2016). Her påpeger hun, at forandringer inden for den mere officielle og organiserede religion også må inkluderes i undersøgelse af samtidsreligion, men fortsat ud fra et 'levet religion'-perspektiv. Det skal ifølge hende primært ske igennem et større fokus generelt på de kropslige og materielle dimensioner af religion i de forskellige kontekster. Hun efterspørger bedre retningslinjer for, hvordan levende religion skal undersøges og foreslår som ramme at undersøge praksisser i "domains of life where sacred things are being produced, encountered and shared", hvor følgende aspekter er centrale: "religion as embodied, material, placed, but also cognitive, emotional, and discursive" (Ammerman 2016, 89). Derfor skal undersøgelserne ikke trække en skarp grænse imellem organiseret religion og hverdagsreligion: "If lived religion is about what people do, starting with an artificial line between organized religion and everyday life is not especially helpful" (ibid.). Det drejer sig altså ikke om en tilbagevenden til en undersøgelse af den elitært formidlede officielle religion, men derimod om en undersøgelse af de foranderlige, rodede og ikke dogmatiskkonsistente praksisformer, som udfolder sig inden for de etablerede religioner.

I vores forskning inden for den danske folkekirke i de senere år har vi ligeledes fokuseret på forandringer i den officielle religion i studier af religion i det senmoderne, og ud fra dette perspektiv fremstår den etablerede religion, den danske folkekirke, på ingen måde konsistent eller uforanderlig, tværtimod. Samtidigt er det igennem forskellige forskningsprojekter blevet klart, at hvad der umiddelbart ser ud som nye aktiviteter, ofte viser en tydelig lighed med klassiske religionsformer. 
Religion og krop

I bogen Ritual and Religion in the Making of Humanity argumenterer den amerikanske antropolog Roy A. Rappaport for, at ritualers altafgørende betydning for religion skal findes i deres unikke kombination af sprogligt baserede antagelser om en transcendent herskende verdensorden med konkrete, kropslige handlinger. I rituelle handlinger får de religiøse antagelser, som hverken kan falsificeres eller verificeres og dermed altid må forblive en trossag, fodfæste gennem de i ritualet forsamlede kroppe, som med deres deltagelse understøtter det religiøse univers' fortsatte betydning og normativitet (Rappaport 1999, 24-68). Denne forståelse indebærer, at ritualer har en stærk kommunikativ dimension, hvor den kropslige rituelle handlen udgør et udsagn både om det religiøse univers (kanoniske meddelelser) og om forholdet mellem deltagerne og det religiøse univers (selvreferentielle meddelelser) (ibid., 52f). Inspireret af antropologen Anthony Wallace understreger Rapport således, at ritualer har både en allo-kommunikativ og en auto-kommunikativ betydning. Den allo-kommunikative dimension betegner de meddelelser, de rituelle handlinger sender til andre i eller uden for ritualet fx om særlige rollers betydning eller om menighedens fortsatte støtte til religionen; men ifølge Rappaport er den auto-kommunikative dimension af mindst ligeså stor betydning. Ritualdeltagerne de der formidler den rituelle kommunikation - er også altid selv blandt de vigtigste modtagere af kommunikationen (ibid., 51).

Den auto-kommunikative dimension peger på ritualers religionsdidaktiske potentiale, fordi ritualdeltagerne med deres rituelle handlen kommunikerer til sig selv (og til andre), hvem de er, og hvor de hører til. Den britiske antropolog Mary Douglas har formuleret dette som en relation mellem makrokosmos og mikrokosmos. I følge Douglas er kroppen et mikrokosmos, som afspejler samfundets makrokosmos. Kroppen er en slags signalpost, som internaliserer, adapterer og udlever de værdier og normer, som makrokosmos gennem kulturel prægning indrammer den enkelte i. Ritualers koreografering af kropslige handlinger drejer sig således ikke alene om at opføre og kommunikere en makrokosmisk orden gennem omhyggelig styring af kropslige handlinger, men om at makrokosmos bliver gyldigt og individuelt repræsenteret, når makrokosmos gennem rituelle handlinger søges internaliseret $\mathrm{i}$ de konkrete kroppe. Den fysiske krop er altid en socialt determineret krop (Douglas 1973, 93). Derved bliver ritualdeltagerne vigtige modtagere af deres egen kommunikative handlen og bliver derved - ideelt set - gennem den rituelle handling indlejret i det betydningsunivers og det religiøse fællesskab, som deres handlinger fortæller dem, at de er del af.

Den canadiske evolutionspsykolog Merlin Donald understreger i sin kortlægning af menneskets biologiske og kulturelle evolution, at menneskets kommunikative kompetence udvikler sig før sproget (Donald 2001, 262-269). Ifølge Donald har mennesket udviklet sig gennem fire erkendelsesfaser. Den første fase er episodisk bevidsthed, som deles med andre pattedyr. Her kan man huske og genkende basale begivenheder og episoder. Den næste fase er den mimetiske, som er udtryk for distinkt menneskelig, men før-sproglig kommunikation. Her kan mennesket ved hjælp af bevægelser og gestik kommunikere og indlære håndværk og kropslige ud- 
tryk som fx dans. De to sidste faser er kendetegnet ved sproglig kompetence. Først mytisk kultur, hvor sproglig mundtlig kultur sætter mennesket i stand til at fortælle historier og dermed skabe myter; og dernæst teoretisk kultur, hvor sproglig skriftlig kultur gør det muligt at lagre viden og dermed udvikle mere kompleks og abstrakt tænkning (Donald 2001, 259-262; Lundager Jensen 2008). I Donalds beskrivelse af menneskets udvikling som et kommunikativt væsen er det en vigtig pointe, at de tidligere faser ikke forsvinder, når nye faser indtræder. De overskrives som den primære kommunikationsform, men er fortsat til stede som kognitive kompetencer, der kan bringes i anvendelse i mødet med verden omkring en. Derfor har Baunvig og Johansen argumenteret for, at det er oplagt at antage, at Donald også kan anvendes som teoretisk baggrund for at forstå forskellige tilgange til ritualer og forskellige aspekter af rituelle handlinger (Baunvig \& Johansen 2014). I forhold til ritualers kropslige auto-kommunikative dimension er Donalds mimetiske erkendelse særlig interessant, fordi han understreger den kropslige efterligning som kommunikativ handlen. Mimetisk kommunikation er båret af kropslige handlinger, som ved at efterligne og indgå i fælles handlinger indlærer og udtrykker betydninger. Det er altså en kommunikationsform, som ikke på forhånd forudsætter kendskab til de religiøse fortællinger (mytisk kultur) eller abstrakt religiøs tænkning (teoretisk kultur), selvom særligt fortællinger naturligvis indgår i ritualer. Ud fra dette perspektiv fremstår en genopdagelse af ritualer og særligt de kropslige auto-kommunikative handlinger som en oplagt vej til fornyelse for en kirke, hvis medlemmer ofte har begrænset kendskab til betydningsuniversets mytologiske og teologiske sammensætning.

Den rituelle fornyelse og nyfortolkning, som i dag finder sted i den danske folkekirke, udfolder sig da også i udpræget grad som en opritualisering og dermed som en kropslig frem for snævert auditiv internalisering af det kristne betydningsunivers. I stort set alle de nye aktiviteter, som har udviklet sig siden midten af 1990'erne, finder man ritualiseringer og praksisformer, som aktiverer kroppen. Det gælder børne- og familiegudstjenester med fællesspisning, skolestartsgudstjenester, stille- og meditationsgudstjenester, pilgrimsvandring, babysalmesang, Halloweengudstjeneste, fastelavnsgudstjeneste, Valentinsgudstjenester og vejledning i faste.

Nye ritualiseringer inden for folkekirken, som fx lystænding, meditation og pilgrimsvandring, er på samme tid gamle, ikke kun fordi de har eksisteret inden for en bred kristen sammenhæng i århundreder, men også ud fra en mere grundlæggende religionshistorisk betragtning: De har alle træk af kropslige ritualiseringer i former, som er meget genkendelige. Der er altså sjældent tale om rituelle opfindelser, men nærmere om rituel genopdagelse. ${ }^{1}$ En af de religionsformer, som er blevet genopdaget og nyfortolket, og som i høj grad er udtryk for et stigende fokus på krop og kropslighed i ritualer, er processioner.

Grundlæggende er processioner en bevægelse baseret på en religiøs koreografi, et ritual som kommunikerer noget til nogen. Der findes en række definitioner og også uenigheder i forskningen (Grimes 2005), og spørgsmålet om nutidige processi-

1 Denne pointe findes også inden for studier af nye religiøse former, se fx Michael Houseman 2007. 
oner har også været berørt i diskussionerne, som fx hos Anne Gronover (Gronover 2006). I indledningsartiklen til dette nummer af Religionsvidenskabelig Tidsskrift fremhæves fire kategorier, på baggrund af særligt Bernhard Langs artikel "Processions" i Religions Past and Present fra 2015: den funktionelle, den hierofore, den mimetiske og den demonstrative. Processioner kan indeholde flere af disse træk samtidigt. Den funktionelle dimension betegner den stiliserede form af en reel og nødvendig flytning, $\mathrm{fx}$ at bære kisten til graven eller føre bruden til alteret. Den hierofore dimension (kaldet den teofore hos Lang) er fremvisningen af et billede eller symbol, som repræsenterer guden eller det hellige. Den mimetiske dimension er en fremstilling af mytiske begivenheder, hvor et forløb, fx påskefortællingen, gennemspilles. Og den demonstrative er en procession, hvor formålet er at vise en bestemt gruppes identitet frem over for tilskuere, som $\mathrm{fx}$ ved en bispeindsættelse eller præstevielse. I den følgende analyse og diskussion af to eksempler på processioner i dag tager vi udgangspunkt i denne kategorisering.

\section{Metode}

Undersøgelsens empiriske grundlag hentes fra to forskellige empiriske studier af nyere folkekirkelige praksisformer, som er blevet analyseret med særligt henblik på procession, men som ikke havde procession som det oprindelige fokus. Der er således ikke inkluderet studier af de officielle, veletablerede ritualer som ordinationsritualet og dåb i denne artikel. Men som baggrund for den rituelle nyfortolkning af processioner i mindre etablerede ritualer er de etablerede processioner og deres funktion kort beskrevet som indledning til analysen nedenfor.

Kirstine Helboe Johansen foretog i oktober-november 2016 et fortrinsvis observationsbaseret studie af folkekirkelige gudstjenester ved Halloween og Alle Helgen. Målet med undersøgelsen var at afdække, hvilke forståelser af relationerne mellem levende og døde, som forkyndes og praktiseres ved disse gudstjenesteformer. I samarbejde med en række forskningsassistenter observeredes over fjorten dage fjorten forskellige gudstjenester fordelt over hele landet. Gudstjenesterne var udvalgt ud fra kirkekalenderen.dk, og udvælgelsen fokuserede på gudstjenester, der involverede flere rum: kirke, sognegård, kirkegård, kælder, kirketårn, kirkeloft - med henblik på at kunne afdække den betydning, som rum og bevægelse mellem rum udgør. Metoden var deltagerobservation ud fra en observationsguide og vejledning for observationsrapport. Ved de fleste gudstjenester var mere end én observatør til stede, og observationsrapporterne er derefter sammenskrevet. Observationerne suppleres af tekstmateriale: liturgier, sangark, annoncer og fotografier taget under observationen. Derudover er alle præster efterfølgende blevet interviewet om den pågældende gudstjeneste og deres tanker bag den. I forhold til denne analyse er en enkelt case udvalgt med henblik på at illustrere, hvorledes procession inddrages $\mathrm{i}$ en sådan gudstjeneste og hvilken rolle den spiller. Case-studiet har således ikke til formål at illustrere en generel tendens, men derimod at vise den dynamik, som udfolder sig ved en konkret procession. 
I 2015 undersøgte Center for SamtidsReligion aktiviteten 'babysalmesang' i den danske folkekirke. ${ }^{2}$ Undersøgelsen kortlagde aktiviteten nationalt og analyserede via spørgeskemaundersøgelser, interviews og deltagerobservation forståelsen af aktiviteten både hos arrangørerne og deltagerne. Denne undersøgelse dokumenterede den høje grad af ritualisering og kropslige praksisformer, som indgår i babysalmesang, men fokuserede primært i de første analyser på motivationen for at udbyde og deltage i aktiviteten. Og i forlængelse heraf hvordan aktiviteten kan forstås som del af et skift til et brugerperspektiv i folkekirken (Nielsen 2015). Efter undersøgelsen blev der etableret kontakt til Aino-Elina Kilpeläinen, Helsinki Universitet, som i samme periode havde udført deltagerobservation af babysalmesang i kirker i Aarhus. ${ }^{3}$ Kilpeläinen havde i den forbindelse optaget en række forløb digitalt. Disse optagelser gjorde det muligt at analysere de rituelle elementer i aktiviteten fra et mere kvalitativt perspektiv. På baggrund af data både fra den store nationale undersøgelse og den mindre kvalitative undersøgelse foretog Marie Vejrup Nielsen og Aino-Elina Kilpeläinen en analyse af de kropslige ritualiseringer, der indgik i en bestemt case. I denne bestemte case indgik procession som et centralt element i aktiviteten.

\section{Processioner i den danske folkekirke}

Processioner er et veletableret fænomen i den danske folkekirke og indgår som del af den forordnede liturgi i to ritualtyper: Initiationsritualer og overgangsritualer. Almindelig praksis knyttet til den autoriserede liturgi i den danske folkekirkes ritualhåndbog fra 1992 ligger til grund for den følgende beskrivelse.

Ordinationsritualet for nye præster og bispeindvielsesritualet for nye biskopper kan begge karakteriseres som initiationsritualer - et individ med særlige forudsætninger, henholdsvis uddannet og kaldet for præsters vedkommende og demokratisk valgt for biskoppers vedkommende, indlemmes ved hjælp af ritualet i en særlig gruppe med særlige opgaver og forpligtelser. I begge ritualer indgår procession som centralt element i ritualets indledning eller afslutning. De nye præster eller den nye biskop føres i procession frem mod alteret i kirken. De nye kandidater er tydeligt markeret med en hvid kjortel og adskiller sig dermed fra de andre deltagere i processionen, som består af allerede indviede kolleger - ved ordination præster i præstekjole, ved bispevielse danske og nordiske biskopper i bispekåbe samt enkelte præster. Ligeledes er procession tydeligvis en offentlig affære, fordi deltagerne på kirkebænkene og ved bispevielse også tilskuerne uden for kirken iagttager processionen uden at deltage i den. Dette gælder i særlig grad ved bispeindsættelse, hvor

2 Undersøgelsen af babysalmesang indgik i et projekt i samarbejde med Danmarks Kirkelige Mediecenter om folkekirken og børnefamilier. Den konkrete undersøgelse var finansieret af Folkekirkens Videnspulje.

3 Aino-Elina Kilpeläinen er Th.D.-student (Doctor of Theology) ved Helsinki Universitet og har religionspædagogik som sit forskningsfelt. Hendes artikler er primært tilgængelige på finsk; men en fællesartikel med Marie Vejrup Nielsen på engelsk er under udgivelse. 
der er repræsentanter tilstede for det offentlige Danmark, såsom kongehus og Folketing. Der er således tale om klassiske demonstrative processioner, hvor en særlig gruppe viser sig frem for menigheden som gruppe med henblik på at indlemme endnu et medlem og dermed overføre den autoritet og rolle, gruppen har, til det nye medlem.

Procession indgår ligeledes i de klassiske overgangsritualer: dåb, konfirmation, vielse og begravelse, men i en ganske anden form. Her er den funktionelle dimension fremtrædende. Ved dåb, vielse og begravelse er det en ganske lille procession, som består af den person, som skal undergå forandringen og ganske få familiemedlemmer. Ved dåben fører præst og forældre dåbsbarnet frem til døbefonten; ved vielse fører faderen bruden frem til alteret og den ventende brudgom; og ved begravelse fører præst og kistebærere kisten med afdøde væk fra alteret til graven eller rustvognen. Konfirmation adskiller sig derfra ved at være en kollektiv procession af ligeværdige, ens klædt i hvide kjoler og pænt tøj, som af præsten føres ind i kirkerummet. Ved disse processioner er det almindelige medlemmer af menigheden, som træder frem for at gennemgå en overgang; og ligesom ved initiationsritualerne udgør menigheden en offentlighed, som iagttager processionen og dermed understøtter ritualets sociale betydning.

Hidtil har processioner i den danske folkekirke først og fremmest bestået af disse to typer, suppleret af mindre regulerede processioner ved for eksempel høstgudstjenester, hvor elementer fra høsten i taksigelse bæres frem til alteret som ved en offerprocession. Processioner har derfor primært indgået som element i ritualer, hvor et enkelt individ eller en mindre gruppe under menighedens bevågenhed skal undergå en forandring.

I nogle af de nye aktiviteter dukker processioner op på ny i anden form og uden for de rituelle rammer, de sædvanligvis har udfoldet sig inden for. Processioner indgår dermed som del i den kreative nyfortolkning af kristne praksisformer. De tilhører ikke alene de klassiske, velregulerede ritualer, men bliver en religiøs praksis, som integreres i mere dagligdags rituelle former såsom børnegudstjenester, babysalmesang og lejlighedsgudstjenester. Når det derfor kan hævdes, at processioner er et nyt element $\mathrm{i}$ det folkekirkelige gudstjenesteliv, handler det således primært om, at processioner i de nye praksisformer ikke er en handling, der er forbeholdt en særlig gruppe eller anledning. Det er en praksisform, som menigheden udfører i fællesskab. Det betyder blandt andet, at skellet mellem rituel aktør og offentlighed udviskes. De to cases, Halloween og babysalmesang, har til formål at illustrere, hvordan processioner indgår og nyfortolkes i konkrete nye praksisformer med henblik på at undersøge, hvilken rolle processioner spiller i aktiviteterne.

\section{Case 1: Fra mørke til lys}

I oktober 2016 fejredes Halloween i en kirke i en større provinsby med en gudstjeneste, der udfoldede sig som menighedens fælles vandring gennem forskellige rum og til forskellige stationer. En stor del af gudstjenesten udfolder sig således som en fælles procession. Udvalgte roller som præst og korleder har særlige opgaver; men processionsdeltagere og offentlighed smelter sammen. 
Gudstjenesten begynder i sognegårdens entre. I entreen er dæmpet belysning med levende lys i stager og græskar, som sætter en stemningsfuld scene. Her samles deltagerne efterhånden, som starttidspunktet nærmer sig, og efterhånden, som flere kommer til, må deltagerne stå tæt sammen for at kunne være der. Stemningen er afventende. Kort før bedeslagene træder præsten frem, hilser velkommen og fortæller kort om Halloween og aftenens gudstjeneste. Derefter beder hun deltagerne lytte til bedeslagene, som markerer gudstjenestens begyndelse. Derefter henledes opmærksomheden på kælderen, hvor der klinges med små bjælder og et pigekor synger. Da sangen afsluttes, bevæger deltagerne sig i fællesskab ned ad trappen og gennem det lille forrum, hvor koret har stået og sunget. Belysningen er fortsat dæmpet med mange levende lys. Målet er ikke forrummet, men en rå kælderskakt, som ligger bagved. Her er næsten helt mørkt med flagermus og skeletter hængende fra loftet. Deltagerne har fået udleveret små lommelygter, som de lyser med på deres tur gennem gangen. Ved enden af gangen stopper præsten deltagerne og samler dem i en halvkreds om et lille tableau med Halloween-udsmykning som edderkopper, spindelvæv og en afhugget fod. I mørket omkring det lettere makabre fad beder præsten deltagerne bede Fadervor i fællesskab. Hun begrunder det med, at selvom der er mørkt og skræmmende i kælderen, skal deltagerne som kristne ikke frygte, men i stedet følge Jesus og bede den bøn, han har lært dem.

Deltagerne beder sammen Fadervor, og derefter fortsætter bevægelsen ud af den rå kældergang til en velholdt og mere oplyst kældergang uden Halloweenudsmykning, men med masser af levende lys i stager. Kældergangen snor sig lidt, og til slut kan deltagerne høre korsang, som kommer ned i kælderen oppefra. Deltagerne går op ad den trappe, som afslutter kældergangen, og som fører dem direkte op til alteret i kirken. I kirken er belysningen dæmpet og omhyggeligt iscenesat. Bag alteret står et kor på fire personer og synger, mens deltagerne guides til at samle sig rundt om alteret. Enkelte sætter sig ned på kirkebænkene, men opfordres til at rejse sig og komme op til alteret. Omkring alteret synger menigheden den første salme, og derefter opfordres de til at tage plads på bænkene i kirkerummet. Resten af gudstjenesten forløber mere traditionelt i vekselvirkning mellem læsninger og prædiken, korsatser og salmesang, selvom om menigheden også under en af salmerne instrueres til en fælles bevægelse, hvor de skal rejse sig og stille sig rundt langs ydervæggene for her at synge en kanon og supplere den med enkle bevægelser. Ved gudstjenestens afslutning opfordres deltagerne til at fortsætte den fælles bevægelse ind i sognegården, hvor der serveres suppe; men den fælles handling opløses, da en del deltagere drager hjem, mens andre deltager i spisningen.

Halloween-gudstjenesten har tydelige lighedstegn med klassiske processioner: En gruppe mennesker føres liturgisk i en fælles bevægelse frem mod alteret i kirken; men denne procession adskiller sig på flere måder fra de klassiske folkekirkelige processioner i initiations- og overgangsritualer. For det første er det ikke et særligt individ eller gruppe, som føres frem af en større gruppe. Bortset fra præsten, som leder procession, er ingen deltagere iklædt en særlig klædedragt eller på anden måde fremhævet som objekt for og centrum i processionen. Præsten fører den samlede menighed frem gennem en række rum og stationer. For det andet er der ingen til- 
skuere til stede. Alle tilstedeværende er del af processioner. Ganske vist har kor, korleder og præst særlige opgaver, som betyder, at de skiller sig ud fra gruppen; men der er ingen offentlighed, ingen menighed, som iagttager processionen. Processionens deltagere og dermed afsendere af processionens budskab og modtagerne af budskabet er således sammenfaldende. Der er ikke andre at kommunikere til end de forsamlede selv. Det betyder, at processionens betydning som display for roller og opgaver mindskes til næsten ingenting; og den må derfor have en anden betydning.

Selvom det ikke ekspliciteres, er Halloween-processionen typologisk i nær forbindelse med israelitternes vandring gennem ørkenen. I stærkt kondenseret form vandrer deltagerne gennem mørke og farer med præsten foran sig som guide og vejviser, indtil de når kirkerummet, hvor der er lyst og godt at være, og hvor deltagerne kan finde ind i en mere vant gudstjenestepraksis på kirkebænkene. Processionen er ligesom vandringen gennem ørkenen ikke til for andres skyld, men søger kropsligt at internalisere bevægelsen i deltagerne, således at de undervejs skal forvandles og blive til det, de gennem dåben faktisk allerede er, kristne mennesker, som i tro på Kristus uden frygt kan møde de farer og trusler, verden måtte byde dem. I stedet for at fortælle en historie om en vandring fra mørke til lys bevæger deltagerne sig gennem erfaring af mørke og uhygge, erfaringen af at stå tæt sammen i mørket som en lille menighed, der trykker sig sammen i værn mod mørket og derefter bevægelsen mod lyset, som bliver stadigt stærkere og understøttes af musik og salmesang. På den måde bliver processionen ikke et offentligt display, men en ritualiseret gruppehandling med gruppen selv som afsender og modtager, og som har til formål kropsligt at understøtte de erfaringer og betydninger, som den samlede gudstjeneste drejer sig om. Den procession, som indgår i lokale kirkers kreative udfoldelse af praksisformer, er således en ganske anden end hidtil. Processionen har dermed en tydelig mimetisk dimension, som trækker på, men også rækker udover Langs beskrivelse af processioners mimetiske dimension. Processionen gennemspiller ikke, eller ikke udelukkende, en mytologisk fortælling, men derimod et grundmenneskeligt vilkår, hvor mørke og lys begge er til stede, og menigheden i kraft af fortællingen om Jesus mindes om, at de i virkeligheden kan møde mørket uden frygt. Den mimetiske dimension viser sig desuden som erkendelsesform derved, at deltagerne gennem processionens kropslige regulering mimer erfaringer af mørke, fællesskab, bøn, lys og salmesang.

Den beskrevne Halloween-gudstjeneste har den mest udfoldede og gennemritualiserede procession, men flere andre observerede gudstjenester i forbindelse med Halloween og Alle Helgen inkluderede lignende elementer. Det kan være procession op til alteret for at tænde lys for afdøde, procession ud af kirkerummet til gravene med tændte lys eller procession gennem kirkegården hen til kirken. Bortset fra et enkelt tilfælde, hvor børn i procession bar græskarhoveder ind i kirken, mens resten af deltagerne så til som ved en offerprocession, var alle processionslignende elementer kendetegnet ved, at de var en fælles handling for alle de forsamlede. Procession er en fælles handling, som har som sit primære formål at understøtte en kropslig erfaring af gudstjenestens tema og betydning, hvad enten det er erindring af afdøde familiemedlemmer eller oplevelse af kontrasten mellem mørke og lys. 
Case 2: Fra døbefonten og tilbage igen

Processionen, der blev observeret ved denne kirkes babysalmesang, er en fast del af forløbet. Efter de første par gange var den således velkendt for deltagerne. Processionen er placeret midtvejs i forløbet, som har fast struktur hver gang: indledning; navneritual inden for alterskranken; procession; døbefontsritual; tørklæderitual; afslutning.

Underviseren af forløbet stiller sig forrest ved foden af trappen op til alteret, så deltagerne står bag hende op til døbefonten. Underviseren holder den dukke, hun bruger til at vise, hvordan man skal holde babyen i de forskellige aktiviteter, op på armen. Hun bærer dukken med ansigtet fremad med ryggen ind mod hende. Mødrene efterligner underviseren og forsøger så vidt muligt at bære babyerne, så de ser fremad. Da alle står på række, begynder musikken spillet af den anden underviser, og mens alle synger, går de i procession, langsomt og rytmisk ned til kirkens indgang, hvor de drejer til højre og standser ved et lystændingsstativ.

Ved lystændingsstativet instrueres mødrene kort i, at nu kan de tænde et lys. Mødrene går op enkeltvis og tænder lys sammen med babyen, de er koncentrerede om aktiviteten. Da alle har tændt lys, afsynges Fadervor i fællesskab.

Derefter stiller underviseren sig igen op med dukken forrest, og alle går i procession tilbage til altertrappen, langsomt og rytmisk, mens der synges. Igen er der fuld koncentration om at gå, synge og holde babyen, mens de bevæger sig i hele kirkens længde tilbage til døbefonten.

Næste aktivitet er ved døbefonten, så mødrene bliver stående i nærheden af den, efter processionen er afsluttet.

Processionen er velkendt for mødrene efter den første gang, og foregår med minimale instruktioner. Der er en koncentreret stemning og fokus på at gå langsomt og synge. Processionen er på en gang kollektiv og individuel. Det primære individuelle aktive element er lystændingen. Der er ingen tilskuere til processionen, og afsendere og modtagere af dette rituals budskab er således sammenfaldende.

I forhold til de typer processioner, som har været dominerende i en folkekirkelige sammenhæng, er der således stor forskel, netop i den manglende tilstedeværelse af en offentlighed eller større menighed. Samtidigt synes der at være ekkoer af praksisformer, som netop har forbindelse til overgangsritualerne, i dette tilfælde barnedåben. Når man ser processionen, er det ikke primært de senmoderne elementer, som tiltrækker sig opmærksomhed, såsom det moderne individ, der udtrykker sig og udvikler sig igennem selvvalgte aktiviteter, men i stedet de ekkoer af genkendelige religionsformer, som ellers i mange modeller er placeret før, og til og med langt før, det moderne og senmoderne. Der er først og fremmest et ekko inden for den kristne tradition og barnedåben som ritual, hvor barnet bæres til og fra dåben. Og dermed også et ekko af netop den dimension af de funktionelle processioner i kirkelige ritualer, hvor lægfolket altid har spillet en rolle: at bære barnet til dåben, at føre bruden op til brylluppet, at bære kisten ud af kirken ved begravelserne. Samtidigt er der et endnu dybere ekko af det, man kunne kalde velsignelsesreligion, hvor barnet bæres igennem det hellige rum og kommer i berøring med forskellige centrale stationer i rummet. I vores analyse sker dette altså uafhængigt af teologiske og 
doktrinære fortolkninger af kirkens rum, hvor fx en protestantisk teologi ikke vil tillægge rummet sakral værdi. Men det gør processionen i bevægelsen fra døbefonten, til lystænding og Fadervor og tilbage igen. Der skabes et rum for både en fælles kommunikation og en individuel kommunikation. Processionen er således indlejret i både barnedåben som ritual og i kirkens øvrige ritualer og symbolsystem, og den kommunikerer på en helt basal måde til og gennem deltagerne. Her taler vi ikke om personlig tro eller stiller spørgsmål om forestillinger om transcendens. I stedet bevæger vi os til at se på religion udtrykt ud fra de mimetiske parametre, hvor det bliver den kropslige indlæring og oplæring, som står i centrum, og ikke den tekstbaserede, sprogligt artikulerede læring.

\section{Mimetisk-didaktiske processioner?}

De nye processioner, som er blevet præsenteret her, viser, at også de etablerede religioner er et åbent og kreativt felt præget af religiøs innovation (Bellah 1964), og de er ligeledes gode eksempler på det, som Nancy Ammerman ser som en stærk tendens i samtidsreligion: her udtrykkes religion som en materiel og stedslig form med stærke emotionelle præg (Ammerman 2016). Samtidigt er processionerne også forbundet til det kognitive og sproglige særligt igennem fælles tale og sang, hvor både salmer og Fadervor forbinder til det tekstbaserede univers. Processionerne finder samtidigt sted inden for en etableret, historisk kirke. De er organiseret og ledes af kirkens personale og trækker på mange elementer fra kristendommens lange historie. De er således grundlæggende gode eksempler på, hvordan levet religion også udvikler sig inden for rammerne af officiel religion i dag.

Men hvordan skal vi forstå disse processioner, hvis vi ikke standser ved disse første konklusioner om den komplekse og konstante udvikling inden for etableret religion?

Selvom Halloween-processionen primært trækker på den mimetiske dimension og babysalmesangsprocessionen primært på den hierofore og funktionelle dimension, så har de betydningsfulde ligheder, hvorved processionerne får en mimetiskdidaktisk funktion, som ikke er snævert knyttet til en mytologisk fortælling, men til en mere udefineret erfaring af fællesskab, rum og betydning.

I begge cases var det tydeligt, at selvom processionerne har lighedstræk med de klassiske processionsformer, så adskiller de sig fra disse derved, at alle ritualdeltagere indgår i en fælles procession. Det er ingen tilskuere at processere for. Det betyder ud fra Rappaports skelnen, at processionernes auto-kommunikative betydning kommer i centrum. Det afgørende ved de genkomne processioner er tilsyneladende ikke at stadfæste eller kommunikere noget over for andre uden for ritualet, men derimod at deltagerne - orkestreret af præsten eller rituallederen - stadfæster og kommunikerer noget over for sig selv. Denne stadfæstelse og kommunikation er imidlertid kun i begrænset omfang sprogligt båret. I det samlede forløb indgår læsninger, salmer og ved Halloween-gudstjenesten en kort prædiken, men i selve processionen er den kropslige bevægelse og det kropslige sanseapparat i centrum: Bar- 
net bæres gennem rummet, man tænder lys, går gennem mørke og uhyggelige rum, gennem lyse rum, og man samles om alter og døbefont. I processionerne ses således en tilbagevenden af kropslighed i et religiøst system, som hidtil har været præget af skepsis over for denne dimension; og heri viser sig en erkendelse af kropslige, ikkesproglige handlinger som kommunikation i sig selv. Det er Donalds mimetiske erkendelse, som er grundlag for processionens auto-kommunikative opbygning: Når deltagerne efterligner den koreograferede bevægelse gennem processionen, giver de kropsligt udtryk til processionens forskellige erfaringsrum. Med Douglas kan man sige, at man med liturgien skaber en tydelig fortælling og dermed en social krop, som de fysiske kroppe indlemmes i og tages til indtægt for, når de indgår i processionen.

Ud fra et sådant perspektiv har processionernes kropslighed et religionsdidaktisk præg: Processionen hviler på mimetisk erkendelse, som er umiddelbart tilgængelig, og er primært auto-kommunikativ med henblik på at deltagerne skal få en erfaring af det budskab, som processionen søger at udtrykke. Et religionsdidaktisk præg er ikke fremmed for processioner som genre: Demonstrative processioner fortæller om særlige gruppers roller og opgaver, mimetiske processioner gennemspiller myter, og hierofore processioner illustrerer guden og relationer mellem guden og helligsted eller lokalområde. Det særlige ved de nye processioners religionsdidaktiske præg er, at de er iscenesat som deltagernes egen-kommunikation, hvorved de ikke lærer om særlige grupper eller myter, men gennem mimetisk erkendelse iscenesættes til en erfaring af sig selv som del af det religiøse univers. I en samtidig kontekst, hvor religiøs indlæring og praksis ofte er begrænset, vil en meget stor del af den folkekirkelige medlemsskare derfor med stor sandsynlighed erfare ritualer som umiddelbar oplevelse og kropslig bevægelse (Baunvig \& Johansen 2013). Og det er dette vilkår, som de genopdukkede processioners stærkt kropslige, mimetiske og autokommunikative præg tilsyneladende tager højde for ved at iscenesætte en kropslig erfaring af delagtighed. Med en stærk mimetisk dimension bliver erfaringen af fællesskab, af aspekter af det religiøse univers som fx velsignelse eller mod gennem bøn og af det særlige rum sat i centrum frem for den ordrighed og sprogbrug, som nogle deltagere vil være fremmede overfor.

Samtidigt er disse processioner i begrænset omfang forankret i en kollektiv kulturel-religiøs praksis. Den intensitet og mening, som eventuelt skabes lige her og nu blandt deltagerne, er forbundet med den konkrete kontekst og varierer efter al sandsynlighed stærkt deltagerne imellem.

De nye processioners centrale læringsaspekt rejser spørgsmålet om, hvorvidt der er et behov for en ny kategori eller udvidelse af en af de allerede etablerede kategorier for processioner. Barnet og moderen bliver introduceret til rummet, dets form, lyde og funktion, så målet ikke er at initiere dem til en ny status, men i stedet at oplære og danne dem i religionens praksis og udtryk. Halloween-deltagerne bliver ført gennem oplevelser af mørke og lys; men målet er ikke først og fremmest fortællingen om Jesu overvindelse af mørket, men erfaringen af, at mørket rent faktisk overvindes. Den nutidige kreative genopdagelse af processioner peger dermed på en religionsdidaktisk dimension ved processioner. Den religionsdidaktiske dimension 
kan med fordel forstås som en udvidelse af den mimetiske dimension, som bliver særligt fremtrædende, hvor processioner fremstår som primært autokommunikative.

\section{Konklusion}

Det er netop den senmoderne, fragmenterede religiøsitet, som danner rammen omkring den genopdukken af gamle religionsformer, som vi ser også i den danske folkekirke i dag. Der er således ikke et modsætningsforhold imellem Bellahs forudsigelser af vores nutid som åben, kreativ og innovativ, og den måde gamle religionsformer bliver aktuelle igen. Tværtimod. Det er netop kollapset af teologisk magt ovenfra og et skifte til et fokus på brugerne af kirken, der er en central faktor i, hvorfor det er muligt at gå på pilgrimsvandring i en luthersk kirke og i bredere forstand inkludere et ufatteligt stort antal nye ritualiseringer i folkekirken. Men det, at de gamle magthierarkier er forsvundet eller i hvert fald eksisterer på helt andre præmisser, betyder netop ikke, at nydannelserne primært kommer i form af fuldstændigt nye praksisformer. I stedet er både institutionen og individet blevet sat frit til at udforske langt større mængder af ressourcer til inspiration for de religiøse udtryk. Og dette fører til, at også meget gamle, og i en dansk sammenhæng næsten glemte praksisformer, dukker op igen.

Samtidigt er disse genopdukkede praksisformer ikke uforandrede af deres nye kontekst eller af de faser, der har gennemspillet sig over århundrederne. De bliver gendannet og udtrykker sig inden for de nuværende rammer. Og analysen af disse to specifikke cases viser klart en tendens inden for denne nydannelse: De processioner, vi har set her, er ikke primært tænkt som kommunikation udadtil eller som bekræftelse på sammenhængen mellem mange forskellige samfundsmæssige sfærer, men fungerer i stedet som kommunikation indadtil, og som en fleksibel kontekst for det senmoderne individs religionsudfoldelse. Der er således ikke tale om en simpel form for 'overlevelse' af en rest af gammel religion, som efter at have været underlagt doktrinær nedfrysning nu under det rette klima tøs op igen og lever videre uforandret. I stedet er der tale om, at de træk, som forskningen i samtidsreligion understreger igen og igen, såsom effekten af høj individualisering og et skift til et brugerperspektiv, bliver en ny kontekst for videreudvikling af religionsformer, som fx processioner.

Disse cases synes at understøtte Bellahs begreb om, at intet er helt tabt. Samtidigt vil vi tilføje, at intet er helt uforandret af de forudgående faser og heller ikke af den fase, det nu optræder i. De gamle former, som dukker op igen, er præget af udviklingen og eksisterer på deres samtids vilkår. De genopdukkede processioner bidrager således med noget, som de altid har kunnet, nemlig kommunikationen gennem den kropslige handling, og samtidig er de under konstant udvikling ind i nye rammer for, hvordan religion udtrykkes i dag. Dette understreger, hvor centralt processioner bør stå i religionsforskningen, og ikke kun i forhold til studiet af religion i fortiden. Studiet af processioner som en del af nutidig religiøs praksis er således et 
centralt element i etableringen af en stærkere dialog mellem religionshistoriske og religionssociologiske perspektiver inden for studiet af samtidsreligion.

\section{LITTERATUR}

Ammerman, Nancy T.

2016 "Lived Religion as an Emerging Field: An assessment of its contours and frontiers", Nordic Journal for Sociology of Religion, 29 (2), 83-97. https://doi.org/10.18261/issn.1890-7008-2016-02-01

Ammerman, Nancy T., ed.

2007 Everyday religion: observing modern religious lives, Oxford: Oxford University Press.

Baunvig, Katrine Frøkjær \& Kirstine Helboe Johansen

2014 "Gudstjeneste og erkendelse - en Donaldsk analyse af gudstjenesten og dens deltagere", Dansk Teologisk Tidsskrift 77 (4), 297-316.

Beckford, James

2003 Social Theory and Religion, Cambridge: Cambridge University Press. https://doi.org/10.1017/CBO9780511520754

Bellah, Robert N.

1964 "Religious Evolution", American Sociological Review 29 (3), 358-374. https://doi.org/10.2307/2091480

2011 Religion in Human Evolution. From the Paleolithic to the Axial Age, Cambridge, MA: The Belknap Press of Harvard University Press. https://doi.org/10.4159/harvard.9780674063099

Davie, Grace

2000 Religion in Modern Europe, Oxford: Oxford University Press.

Donald, Merlin

2001 A Mind So Rare. The Evolution of Human Consciousness, New York: W.W. Norton.

Douglas, Mary

1973 Natural Symbols, Middlesex: Penguin Books [1970].

Grimes, Ronald L.

2005 “Procession (1987)”, in: Lindsay Jones, ed., Encyclopedia of Religion, 2. ed., Detroit: Macmillan Reference, 7416-7418.

Gronover, Annemarie

2006 "Procession", in: The Brill Dictionary of Religion, Leiden: Brill, 1508-1510.

Hall, David, ed.

1997 Lived Religion in America: Toward a History of Practice, Princeton, NJ: Princeton University Press.

Heelas, Paul

2005 The Spiritual Revolution: why religion is giving way to spirituality, Malden, MA: Blackwell.

Houseman, Michael

2007 "Menstrual Slaps and First Blood Celebrations: Inference, Simulation and the Learning of Ritual", in: David Berliner \& Ramon Sarró, eds., Learning Religion. Anthropological Approaches, New York: Berghan Books: 31-48.

Johansen, Kirstine Helboe

2009 Den nødvendige balance: En ritualteoretisk og praktisk teologisk analyse af højmessen mellem magi og symbol, Aarhus Universitet.

Johansen, Kirstine Helboe \& Marie Vejrup Nielsen

2015 "Choosing a Pastor for the Day: Representations of the Pastor in a Contemporary Context", Journal of Empirical Theology 28 (2), 226-241. https://doi.org/10.1163/15709256-12341326 
Lang, Bernhard

2015 "Processions", Religion Past and Present. Encyclopedia of Theology and Religion, Brill: Leiden. Online. http://doi.org/10.1163/1877-5888_rpp_COM_024492

Lundager Jensen, Hans J.

2008 “Kognition og Kultur, Religionsvidenskabeligt Tidsskrift 51, 20-40.

2011 "Religionshistorie og aksetid: om Robert Bellahs udkast til en evolutionær religionshistorie", Religionsvidenskabeligt Tidsskrift 56, 5-22.

McGuire, Meredith

2002 Religion: the Social Context, Belmont CA: Wadsworth Thomson Learning.

2008 Lived religion: faith and practice in everyday life, Oxford: Oxford University Press. https://doi.org/10.1093/acprof:oso/9780195172621.001.0001

Nielsen, Bent Flemming

2004 Genopførelser. Ritual, Kommunikation og kirke, Frederiksberg: Anis.

Nielsen, Marie Vejrup

2015 "Changing patterns? Occasional Consumers of New Activities in Old Churches", Nordic Journal of Religion and Society 28 (2), 137-153.

Orsi, Robert

2003 "Is the Study of Lived Religion Irrelevant to the World We Live in? Special Presidential Plenary Address, Society for the Scientific Study of Religion, Salt Lake City, November 2, 2002", Journal for the Scientific Study of Religion 42 (2), 169-174.

Rappaport, Roy A.

1999 Ritual and Religion in the Making of Humanity, Cambridge: Cambridge University Press. https://doi.org/10.1017/CBO9780511814686

Kirstine Helboe Johansen, lektor, ph.d., Afdeling for Kirkehistorie og Praktisk Teologi, Aarhus Universitet kp@cas.au.dk

Marie Vejrup Nielsen, lektor, ph.d., Afdeling for Religionsvidenskab, Aarhus Universitet mon@cas.au.dk 